\title{
Assessment of infection control measures in primary health care units in Assiut Governorate
}

\author{
Ekram M Abdel Khalek*, Mohammad H. Qayed*, Enas M Abd El-Megeed**, Noha \\ A Abdelnaby*** \\ * Public Health and Community Medicine Department, ** Microbiology and \\ Immunology Department, Faculty of Medicine, Assiut University, ***Assiut Health \\ Directorate \\ Received, July 2015, accepted October2015
}

\begin{abstract}
Background: Thousands of people die every day around the world from infections acquired while receiving health care. Infection control encompasses the processes and activities that identify and reduce the risks of acquiring and transmitting endemic or epidemic infections among individuals. Aim of the study: The aim is assessment of infection control measures at the primary health care units in Assiut Governorate. Materials and Methods: The present study is a cross-sectional study that had been conducted in three districts out of the eleven districts composing Assiut Governorate. The three districts had been randomly selected and they are Assiut District (include urban and rural areas), Al-fat-h District and Sedfa District. The study covered all the primary health care units located in these three districts during the period from August 2013 to January 2014. Data were analyzed using SPSS version 16. Results: This study totally covered the 79 primary health care units and it was found that $94.9 \%$ of the units their physicians were trained on infection control program, while all nurses were trained on infection control. As a total, Rural Assiut had the highest mean percentage $(53.52 \pm 5.33)$. The highest mean percentage in administrative measures was found in West Assiut Neighborhood Administration (64.98 \pm 6.09$)$. Conclusion and Recommendations: There are statistically significant differences among the studied areas in all aspects of infection control as general, rural Assiut had the highest mean percentage. Continuous supervision and take an action against any person does not follow these procedures will help in rise the level of infection control in primary health care units in Assiut Governorate.
\end{abstract}

Keywords: assessment, measures, infection control, primary health care units.

*corresponding author, Email: habeba2002eg@yahoo.com( Ekram M Abdel Khalek)

\section{Introduction}

The safe and sustainable management of health care infection control is a public health important and a responsibility of all. Improper management of health care source of infection poses a significant risk to patients, health care workers and the community. The right investment of resources and commitment will result in a marked reduction of disease burden and corresponding saving in health expenditures (1). Infection control program in Egypt had been begun since 2003, the Ministry of Health and Population had been applied the program in 5 governorates every year. The program was applied in Assiut in 2008; first at the level of 
central, general and specialized hospitals then in all primary health care units since $2010^{(2)}$. Primary health care is what happens when someone who is ill (or who thinks he or she is ill or who wants to avoid getting ill) consults a health professional in a community setting for advice, tests, treatment or referral to specialist care. Such care should be holistic, balanced, personalized, rigorous and equitable, and delivered by reflexive practitioners who recognize their own limitations and draw appropriately on the strengths of others $(3,4)$. Infection control in developing countries differs markedly from that in the developed countries. Developing countries are recognized as being in a phase of health transition ${ }^{(5)}$. In developed countries infection control is a politically sensitive issue because it improves public health, is cost-effective ${ }^{(6,7)}$. The strategic plan for infection control program in Egypt included setting up an organizational structure, developing infection control national guidelines, training health care workers, promoting occupational safety, and establishing a system for monitoring and evaluation (8). Infection control prevention strategies will help to prevent the transmission of potentially microorganisms. The advantages of involving local experts in the development of such policies are emphasized ${ }^{(9)}$. Many challenges were faced, including administrative, financial, and motivational difficulties. Future plans include expansion of the program to cover all 27 governorates of Egypt and establishment of a surveillance system for hospital- acquired infections. The process of developing the infection control program in Egypt may serve as a model for other resource-limited countries that seek to initiate similar programs (10). The goal of minimizing health care associated infections in our health care facilities can only be realized through commitment and rigorous execution of roles and responsibilities by the health care workers and managers at the all levels.

\section{Aim of the study:}

The present study aims to assess the infection control measures at the primary health care units in Assiut Governorate.

\section{Materials and Methods:}

The present study is a descriptive cross-sectional study which had been conducted in three districts in Assiut Governorate, namely they are Al-fat-h District, Sedfa District and Assiut District. The three districts were randomly selected from the eleven districts compose Assiut Governorate. Assiut District includes East and West neighborhoods as urban areas in addition to the group of villages affiliated to the district as rural areas. The total number of primary health care units in Assiut Governorate is 248 units. All of them are covered by the Infection Control Program (ICP). The primary health care units that located in the selected study districts are 79 units, all of them were included in the study (total coverage).

\section{Instrument}


The data from the target primary health care units had been collected by using a specific checklist as an approved and documented tool for data collection designed by the Ministry of Health and Population "MOHP" (11). This checklist composed of certain indicators necessary to evaluate certain measures of infection control in primary health care facilities and fulfilling the objective of this study.

\section{The checklist covers the following topics:}

- Administrative measures (collected information about staff members, staff training, infection control committee, availability of national infection control guide for all health care workers etc...)

- General cleanliness of each unit.

- Infrastructure.

- Availability of infection control requirements in the store of the unit.

- Availability of drugs in the pharmacy of the unit.

- Assessment of infection control measures in each clinic in the unit.

Numerical criteria for each category of compliance have been established to score and assess whether the established standards have been met or not met. Not met (0), acceptable partially met (1) and fully met (2).

In administrative measures the score is as follows: Not met (0), unacceptable partially met (1), acceptable partially met (2), and fully met (4).
The scoring system for some aspects of unit cleanness is not met (0), unacceptable partially met (2), acceptable partially met (4) and fully met (6).

The scoring criteria proposed to measure the accreditation standards range from 0 to 3 according to the followings:

Score $=0$ (not met). This is the least score, indicating absolute noncompliance with all requirements of the standards. It indicates that the performed activity has not been achieved or the standard/ function is unavailable.

Score $=1$ (partially met, unacceptable). This score indicates that most of the performed activities under this standard are not complete or have not been achieved at an acceptable level of quality.

Score $=2$ (partially met, acceptable). This score indicates that most of the performed activities under this standard are complete and have achieved an acceptable level of quality.

Score $=3$ (fully met). This is a perfect score indicating that all the requirements of the standards have been fully met.

Not Applicable applies to tasks or activities that are not applicable to the task. The "not applicable" scores will be excluded from the calculation of the average score.

The total marks of the evaluation are 648 that distributed on the main items as the followings: 34 for administrative measures which represents $7 \%, 36$ for 
infrastructure representing $7.5 \%, 40$ for infection control equipments and materials that represents $8.5 \%, 46$ for unit cleanliness which represents $9.5 \%$ and lastly 492 for the commitment to infection control recommended procedures. Because there are certain items that not applicable in some units, total marks for each unit is not necessary be the same. So, the mean percentages were calculated to compare different units and infection control measures. Total marks for each unit was calculated giving the total score and mean average for each aspect of infection control measures were calculated by dividing the total marks of the items of each measure on the numbers of their items giving the mean score.

\section{Ethical considerations}

Formal administrative approvals were taken before the start of the study. These included approval by the Ethical Review Committee of Assiut Faculty of Medicine, also include approval by the Directorate of Health. Confidentiality of the data was assured.

\section{Data collection}

Before starting data collection, a pilot study was carried out on one unit which did not include in the study. Data collection started on August 2013 to February 2014. Primary health care unit visit took about one and half an hour.

\section{$\underline{\text { Statistical analysis }}$}

Data were analyzed using SPSS (version 16). The frequencies, percentages, the mean and standard deviation were computed. The ANOVA test was used as the test of significance. The 5\% level was chosen as the level of significance.

\section{Results}

Table (1) shows that the total number of the primary health care units included in this study was 79 units that distributed in three randomly selected districts as follows: 28 units in rural areas of Assiut District representing $35.4 \%$ and 23 units in urban areas which includes East and West neighborhoods administrations representing 29.1\%, Al-Fat-h District included 18 units representing 22.8\% and Sedfa District included 10 units representing $12.7 \%$. Table (2) shows that the physicians in $94.9 \%$ of the studied primary health care units were trained on infection control program, while all participated nurses were trained on infection control program. An infection control manual was available for all employees and more than $90 \%$ of the technicians and workers were vaccinated against viral hepatitis B. There was a nurse responsible for infection control in all of the studied units. Table (3) shows that the number of cleaning workers in the unit was proportionate to the size of the work and all of them were trained on infection control program. Personal protective equipment was available for all workers. It was found 
that $30.4 \%$ of the visited units their cleaning workers committed to the use of personal protective equipment. Assessment of infrastructure was shown in Table (4) that adapted for infection control in $69.9 \%$ of the studied primary health care units. It was found that $27.8 \%$ of the studied units had a clean room special for central sterilization (available in 22 units) and these units had written policies for central sterilization, while $72.2 \%$ (57 units) their sterilization occurred in separated rooms. The presence of a well-sealed room as storage for medical waste was found in $96.2 \%$ of the studied units and this room was confirmed to standards in $60.8 \%$.The stored waste did not exceed 3 days in $34.2 \%$, no opened bags in the rooms were found in $49.9 \%$ and final disposal of medical waste was done outside the all visited units. Table (5) presents the equipments and material stock for infection control in the studied primary health care units. It shows that $86.1 \%$ of the units had soaps for hand washing and instruments cleaning in their store. Clean latex gloves were available in $88.6 \%$ of the units, sterile latex gloves were found in $29.1 \%$, heavy duty gloves were available in $84.8 \%$ and standard masks were available in $87.3 \%$. Single-use plastic gowns were found in $50.6 \%$.Enough syringes for patients were found in one third of the units (32.9\%), cannula and intravenous devices were available in $17.7 \%$. Alcohol was found in $6.3 \%$. Skin disinfectants were available in $58.2 \%$. Heat intolerable disinfectants for instruments, betadine foam and indicators for sterilization were not found in the all visited units. The tools for environmental cleaning and waste segregation requirements were available in $91.1 \%$ and $89.9 \%$, respectively. Table (6) shows that there are statistically significant differences among the 5 studied areas in the infection control measures. As a total, Rural Assiut had the highest mean percentage $(53.52 \pm 5.33)$. The highest mean percentage in administrative measures was found in West Assiut Neighborhood Administration $64.98 \pm$ 6.09 with range from 58.8 to 76.5 , followed by rural Assiut (62.93 \pm 3.77 ) and East Assiut Neighborhood Administration $(62.74 \pm 4.75)$. On the other hand, Al-Fat-h and Sedfa Districts had the lowest mean percentage $(58.99 \pm 5.11$ and $58.83 \pm$ 7.98). In unit cleanliness, East Assiut Neighborhood Administration registered the highest mean percentage (36.05 \pm 16.27$)$ with a range from 19.6 to 71.7 followed by West Assiut Neighborhood Administration (34.99 \pm 14.95), while Sedfa District had the lowest one $(17.15 \pm 4.16)$. In the infrastructure, the highest mean percentage was calculated for rural Assiut (53.27 \pm 17.31), while East Assiut Neighborhood Administration was in the last position $(25.23 \pm 3.45)$. In the requirements, the highest mean percentage was found in rural Assiut $(55.89 \pm 23.21)$ while the lowest one (32.27 \pm 16.41$)$ was found in West Assiut Neighborhood Administration. As regarding commitment to infection control recommended procedures, the 
highest mean percentage was found in rural Assiut (56.12 \pm 3.89$)$.

\section{Discussion}

As with all other functions of a primary health care unit, the ultimate responsibility for prevention and control of infection rests on the health team. The infection control program is effective so long as it is comprehensive and includes surveillance and prevention activities, as well as staff training. There must also be effective support at national and regional levels ${ }^{(12)}$.There are limited published data reporting the infection control in primary health care units in Egypt ${ }^{(10,}$ 13). The present study is the first study conducted for assessment of infection control measures in primary health care units in Assiut Governorate. The present study included 79 primary health care units, $64.5 \%$ of them located in Assiut District this is because Assiut is the capital city of Assiut Governorate and occupies around $23 \mathrm{sq} \mathrm{Km}$. Therefore a political support and commitment is essential in effectiveness of all other measures ${ }^{(14)}$. The present study found that the mean percentage of the administrative measures was high in West Assiut Neighborhood Administration and low in Sedfa District. The mean percentage of all districts in administrative measures was high which can be explained by the continuous training of the health team members despite the turnover of the doctors in the units whatever this training was local from Assiut Health Directorate or central from the
Ministry of Health and Population, also due to the presence of special nurse responsible for infection control in each unit and the availability of the national guide for infection control to all employees. In comparison there was study done about evaluation of infection control in primary health care centers at Zagazeg District, comparative study between accredited and non-accredited health centers ${ }^{(13)}$. The researchers found that the accredited health centers had higher score than non- accredited health centers (45\% and 35\%, respectively). Effective functioning of health care settings depends on a number of environmental requirements, including safe and sufficient water, basic sanitation, adequate management of health care waste, appropriate knowledge and application of hygiene, and adequate ventilation ${ }^{(15)}$. Regarding unit cleanliness, it noted that most of the units had low mean percentage. The highest mean percentage was in East Assiut Neighborhood administration and West Assiut Neighborhood administration and this two places were located in urban area which may be more clean than rural one while the other districts were located in rural areas, also the workers did not do their work appropriately in addition it was found that at many units there were handicapped workers who did not doing their job as normal ones. In Zagazeg study, Fouda and his colleagues reported that the accredited health centers had higher score than non-accredited one in unit cleanliness $(40 \% \text { and } 25 \% \text {, respectively })^{(13)}$. As the 
regards infrastructure, it was found that about two thirds of the studied primary health care units had mean percentage $38.08 \pm 17.69$. It was noted that the mean percentage in Rural Assiut District was high and the other districts had low mean percentages. This finding may be explained as there was plan from Ministry of Health and Population for the improvement and development of primary health care units, whether if this development was by replacement and renovation of whole the unit or building of new units and these units were equipped with infection control procedures, i.e. the walls of the procedures rooms are mounted with ceramics up to the roof of these rooms and the presence of special sterilization room and another room for collection of waste and this development was done in several units in Rural Assiut. In consistent with the present study, Borg in his research in prevention and control of healthcare associated infections within developing countries reported that the infrastructure of health care facilities in some of the poorer nations often lacks basic requirements for the prevention of transmission of infectious diseases ${ }^{(16)}$. On the other hand, in Al-fat-h and Sedfa Districts, the improvement and development was done for few numbers of the units in each district. About East Assiut Neighborhood Administration and West Assiut Neighborhood Administration there was development for only two units and many units were not developed up till now and the health service presented in the current places which are apartments rented and follow Assiut Health Directorate. In comparison to Zagazeeg study, infrastructure was high in accredited health centers than non-accredited one (83.3\% and 63\%, respectively). In requirements, Rural Assiut and East Assiut Neighborhood Administration had high mean percentages than the other districts, due to the availability of these requirements from Assiut Health Directorate as there are one or two orders for infection control supplies per year for all primary healthcare units all over the governorate and each district takes its share from these supplies and distribute it to its units according to the consumption of each unit but there was mal use of these equipment and supplies, so that each unit buys these supplies on the expense of itself when there is shortage. While in Zagazeg study the accredited health centers had high score than nonaccredited one $(81.8 \%$ and $68.2 \%$, respectively $)^{(13)}$. Regarding procedures measures, the highest mean percentage was in Rural Assiut District followed by Sedfa District due to continuous supervision from the health administration team and availability of infection control supplies and equipments and it was low in other districts. There are another results related to Monoufia Governorate ${ }^{(18)}$. The total score of each district as follows; Shebin Al-com (74.2\%), Ashmoun District (66.6\%), Quisna District (71.8\%), Tala District (78\%), Al shohadaa District (50.7\%), Monouf District $(69.5 \%)$, Al-bagour District (69.3\%), Berket Al-sabaa District 
(71.7\%) and Al-sadat District $(56 \%)$.This was the best governorate all over Egypt in following infection control measures. Similar to our findings, poor infrastructure, insufficient equipment, understaffing were reported as common barriers to effective implementation of infection control in many studies in developing countries $(5,19,20)$. Lynch et al. reported that limited resources represent the main challenge for governments in developing countries ${ }^{(21)}$.

\section{Conclusion and Recommendations:}

The administrative measures were adequate in all the studied units. There are statistically significant differences among the 5 studied areas in all aspects of infection control measures. The Rural Assiut District had the highest marks.

The main recommendations of the present study are:

1- Availability of equipment and supplies for infection control and rationalize its consumption.

2- Continuous training to all health care workers in all primary health care units not only doctors and nurses and this besides on-job training.

3- Continuous supervision from Assiut Directorate of Health and health managements in all districts to ensure commitment of the health care workers in the units to infection control procedures.
4- Further research studies and indepth interviews with service providers should be conducted to determine the status quo with regard to practices, skills, knowledge, staffing.

Acknowledgements:The researchers are greatly honored to express their thanks and deepest gratitude to the head of infection control administration at Assiut health directorate for his support. Great thanks to all personnel worked in primary health care units in the three included districts, Assiut Governorate for their help.

\section{References}

1) WHO (2008): Global burden of disease [Internet cited 2014 December 10]. Available from: ww.who.int/healthinfo/global_burde n_disease/2008_report_update/en/in de $\mathrm{x} . \mathrm{html}$

2) Ministry of Health and Population Egypt (2013): Primary health care services and programs in primary health care units.

3) Larson EB, Fihn SD and Kirk LM (2004): The future of general internal medicine: report and recommendations from the Society of General Internal Medicine (SGIM). Task Force on the domain of general internal medicine. J Gen Intern Med; 28 (19): 69- 67.

4) Toop L (1998): Primary care: core values. Patient centered primary care. Br Med J; 316:1882-1883.

5) Raza MW, Kazi BM, Mustafa $M$ and Gould FK (2004): Developing countries have their own characteristic problems with 
infection control. J Hos Infect; 57: 294- 299.

6) Plowman R, Graves $\mathbf{N}$ and Griffin MA (2001): The rate and cost of hospital-acquired infections occurring in patients admitted to selected specialties of a district general hospital in England and the national burden imposed. $\mathbf{J}$ Hos Infect; 47: 198 - 220.

7) Minooee A and Rickman LS (2000): Expanding the role of the infection control professional in the cost-effective use of antibiotics. Am J Infect Control; 28 (1): 57- 65

8) Assiut Health Directorate, Head of Infection Control Administration (2014a): History of application of infection control program in Egypt.

9) Sydnor E R and Perl TM (2011): Hospital epidemiology and infection control in acute care settings. Clin Microbiol Rev; 24(1): 141- 173.

10) Talaat $M$, KandeelA, Rasslan $O$, Hajjeh R, Hallaj Z, El-Sayed N and Mahoney $F$ (2006): Evolution of infection control in Egypt: Achievement and challenges. Am J Infect Control; 34:193- 200.

11) Assiut Health Directorate, Head of Infection Control Administration (2013): Copy of the documented checklist for assessment of infection control measures in primary health care units in Assiut Governorate.

12) WHO (2004): Practical Guidelines for Infection Control in Health Care Facilities. World Health Organization. SEARO Regional Publication No. 41 WPRO Regional Publication.

13) Fouda MA, Ragab HR, Mohamed SE and Aly MS (2012): Evaluation of infection control in primary health care centers at Zagazig District. A comparative study between accredited and nonaccreditted centers. Zagazic University Medical Journal; 18 (3): 548- 553.

14) Raka $L$ and Mulliqi-Osmani $G$ (2012): Infection Control in Developing World: infection Control - Updates. Dr. Christopher Sudhakar (Ed.), ISBN: 978-95351-0055-3, InTech, Available from:

http://www.intechopen.com/books/ infection- control- updates/ infection-control-in-developingworld.

15) Regional Committee for the Eastern Mediterranean (2010): Infection prevention and control in health care: time for collaborative action. Technical paper. Fiftyseventh Session. Agenda item 4 (d).

16) Borg MA (2010): Prevention and control of health care associated infections within developing countries. International Journal of Infection Control; 6: i1- i6.

17) Assiut Health Directorate, Head of Infection Control Administration (2014b): Results of assessment of health administrations of Assiut Governorate according to infection control program.

18) Assiut Health Directorate, Head of Infection Control Administration (2014c): Results of assessment of health administrations of Monoufia Governorate according to infection control program, personal communication.

19) Allegranzi B, Nejad $S B$ and Combescure C (2011): Burden of endemic health care-associated infection in developing countries: systematic review and metaanalysis. Lancet; 377: 228- 241.

20) Bat-Erdene I, Jon A, Anthony $M$, Michael Wand Archie C (2012): 
Perceptions of health care professionals regarding the main challenges and barriers to effective hospital infection control in Mongolia: a qualitative study. BMC Infectious Diseases; 12: 170178.
21) Lynch P, Pittet D, Borg MA and Mehtar S (2007): Infection control in countries with limited resources. J Hosp Infect; 65: 148150. 
Table (1): Distribution of the primary health care units in the study sites, Assiut Governorate, 2014

\begin{tabular}{|c|c|c|}
\hline \multirow{2}{*}{ Study sites } & \multicolumn{2}{|c|}{ Primary health care units in the study sites } \\
\hline & No. $(n=79)$ & $\%$ \\
\hline I. Assiut District & 51 & 64.6 \\
\hline I.1. Rural Assiut District & 28 & 35.4 \\
\hline I.2. Urban Assiut District & 23 & 29.1 \\
\hline $\begin{array}{l}\text { I.2.1. East } \quad \text { Assiut } \\
\text { Neighborhood }\end{array}$ & 12 & 15.2 \\
\hline $\begin{array}{l}\text { I.2.2. West } \\
\text { Neighborhood }\end{array}$ & 11 & 13.9 \\
\hline II. Al-Fat-h District & 18 & 22.8 \\
\hline III. Sedfa District & 10 & 12.7 \\
\hline
\end{tabular}

Table (2): Assessment of administrative measures in the study sites, Assiut

Governorate, 2014

\begin{tabular}{|l|c|c|c|c|}
\hline \multirow{2}{*}{ Items of assessment } & \multicolumn{3}{c|}{ No.= 79 } \\
\cline { 2 - 5 } & \multicolumn{2}{|c|}{ Yes } & \multicolumn{2}{c|}{ No } \\
\cline { 2 - 5 } & No. & No. & \% \\
\hline $\begin{array}{l}\text { 1- Physicians in the unit were trained on infection } \\
\text { control. }\end{array}$ & 75 & 94.9 & 4 & 5.1 \\
\hline $\begin{array}{l}\text { 2- Nursing staff in the unit were trained on } \\
\text { infection control. }\end{array}$ & 79 & 100.0 & 0 & 0.0 \\
\hline 3- There was an Infection Control Committee & 79 & 100.0 & 0 & 0.0 \\
\hline $\begin{array}{l}\text { 4- Committee meetings were regular (at least } \\
\text { every month). }\end{array}$ & 0 & 0.0 & 79 & 100.0 \\
\hline $\begin{array}{l}\text { 5- There were recommendations for action to the } \\
\text { health team for improvement and work in line } \\
\text { with infection control. }\end{array}$ & 0 & 0.0 & 79 & 100.0 \\
\hline $\begin{array}{l}\text { 6- Recommendations for action were written and } \\
\text { documented. }\end{array}$ & 0 & 0.0 & 79 & 100.0 \\
\hline $\begin{array}{l}\text { 7- There is a nurse responsible for infection } \\
\text { control. }\end{array}$ & 79 & 100.0 & 0 & 0.0 \\
\hline 8- Daily supervision was documented. & 61 & 77.2 & 18 & 22.8 \\
\hline $\begin{array}{l}\text { 9- Training of the health team according to } \\
\text { timetable was documented and subjective. }\end{array}$ & 63 & 79.7 & 16 & 20.3 \\
\hline $\begin{array}{l}\text { 10- There were written and approved policies for } \\
\text { infection control. }\end{array}$ & 79 & 100.0 & 0 & 0.0 \\
\hline $\begin{array}{l}\text { 11- Infection control manual was available for all } \\
\text { employees }\end{array}$ & 79 & 100.0 & 0 & 0.0 \\
\hline $\begin{array}{l}\text { 12- More than 90\% of the technicians and } \\
\text { workers were vaccinated against viral } \\
\text { hepatitis B. }\end{array}$ & 79 & 100.0 & 0 & 0.0 \\
\hline
\end{tabular}


Table (3): Assessment of cleanliness in the study sites, Assiut Governorate, 2014 (No.=79)

\begin{tabular}{|c|c|c|c|c|}
\hline \multirow[t]{2}{*}{ Items of assessment } & \multicolumn{2}{|c|}{ Yes } & \multicolumn{2}{|c|}{ No } \\
\hline & No. & $\%$ & No. & $\%$ \\
\hline $\begin{array}{l}\text { 1- Number of the cleaning workers in the study units was } \\
\text { optimum to manage the work. }\end{array}$ & 79 & $\begin{array}{c}100 . \\
0\end{array}$ & 0 & 0.0 \\
\hline $\begin{array}{l}\text { 2- Number of cleaning workers who received training on } \\
\text { infection control. }\end{array}$ & 79 & $\begin{array}{c}100 . \\
0\end{array}$ & 0 & 0.0 \\
\hline $\begin{array}{l}\text { 3- Availability of personal protective equipment for } \\
\text { cleaners. }\end{array}$ & 79 & $\begin{array}{c}100 . \\
0\end{array}$ & 0 & 0.0 \\
\hline 4- Commitment to use the personal protective equipment. & 24 & 30.4 & 55 & 69.6 \\
\hline 5- Availability of cleanliness timetable at the unit. & 6 & 7.6 & 73 & 92.4 \\
\hline 6- Clean toilets. & 7 & 8.9 & 72 & 91.1 \\
\hline 7- Clean floors and corridors. & 29 & 36.7 & 50 & 63.3 \\
\hline 8- Clean walls and ceilings. & 40 & 50.6 & 39 & 49.4 \\
\hline 9- Clean processing rooms. & 79 & $\begin{array}{c}100 . \\
0\end{array}$ & 0 & 0.0 \\
\hline 10- Clean unit's yard. & 25 & 31.6 & 54 & 68.4 \\
\hline $\begin{array}{l}\text { 11- Availability of a written and declared policy for } \\
\text { cleanliness. }\end{array}$ & 14 & 17.7 & 65 & 82.3 \\
\hline
\end{tabular}


Table (4): Assessment of infrastructure in the study sites, Assiut Governorate, 2014

\begin{tabular}{|c|c|c|c|c|}
\hline \multirow{3}{*}{ Items of assessment } & \multicolumn{4}{|c|}{ No. $=79$} \\
\hline & \multicolumn{2}{|c|}{ Yes } & \multicolumn{2}{|c|}{ No } \\
\hline & No. & $\%$ & No & $\%$ \\
\hline 1- Infrastructure is suitable for infection control. & 55 & 69.6 & 24 & 30.4 \\
\hline $\begin{array}{l}\text { 2- The team modify the infrastructure when needed to } \\
\text { achieve the purposes. }\end{array}$ & 0 & 0.0 & 79 & 100.0 \\
\hline $\begin{array}{l}\text { 3- Proper management of time, temperature, and } \\
\text { disinfectants. }\end{array}$ & 17 & 21.5 & 62 & 78.5 \\
\hline 4- There was a sterilization room. & 22 & 27.8 & 57 & 72.2 \\
\hline $\begin{array}{l}\text { 5- Proper management of sterilization regarding time, } \\
\text { temperature, and pressure. }\end{array}$ & 19 & 24.1 & 60 & 75.9 \\
\hline $\begin{array}{l}\text { 6- Using sterilization indicators to assess the process of } \\
\text { sterilization (sterilization reagents). }\end{array}$ & 0 & 0.0 & 79 & 100.0 \\
\hline $\begin{array}{l}\text { 7- Sterile instruments and requirements were packed and } \\
\text { stored properly. }\end{array}$ & 18 & 22.8 & 61 & 77.2 \\
\hline 8- There were written policies of central sterilization. & 22 & 27.8 & 57 & 72.2 \\
\hline $\begin{array}{l}\text { 9- Proper management of contaminated instruments (soaks in } \\
\text { water and soap for } 15 \text { minutes and then washed with } \\
\text { current water). }\end{array}$ & 21 & 26.6 & 58 & 73.4 \\
\hline 10- Availability of cleaning materials. & 22 & 27.8 & 57 & 72.2 \\
\hline 11- Sterilization machines operated efficiently. & 27 & 34.2 & 52 & 65.8 \\
\hline 12- There was room (pot) for the storage of medical waste. & 76 & 96.2 & 3 & 3.8 \\
\hline 13- The room (pot) is well-sealed. & 76 & 96.2 & 3 & 3.8 \\
\hline $\begin{array}{l}\text { 14- The room fulfills the predetermined criteria, regarding } \\
\text { space, ventilation, easy cleaning, source of water, sewage } \\
\text { disposal. }\end{array}$ & 48 & 60.8 & 31 & 39.2 \\
\hline $\begin{array}{l}\text { 15- Medical waste was disposed regularly (the period don't } \\
\text { exceed three days). }\end{array}$ & 27 & 34.2 & 52 & 65.8 \\
\hline 16- No medical waste stored outside the storage room (pot). & 0 & 0.0 & 79 & 100.0 \\
\hline 17- No open bags inside the storage room (pot). & 75 & 94.9 & 4 & 5.1 \\
\hline 18- Final disposal of medical wastes done outside the unit. & 79 & 100.0 & 0 & 0.0 \\
\hline
\end{tabular}


Table (5): Stock of the equipments and materials for infection control in the study sites, Assiut Governorate, 2014

\begin{tabular}{|c|c|c|c|c|}
\hline \multirow{3}{*}{$\begin{array}{l}\text { Availability of equipments and materials for infection } \\
\text { control in the study sites }\end{array}$} & \multicolumn{4}{|c|}{ No. $=79$} \\
\hline & \multicolumn{2}{|c|}{ Available } & \multicolumn{2}{|c|}{ Not available } \\
\hline & No. & $\%$ & No. & $\%$ \\
\hline \multicolumn{5}{|l|}{ I- At store: } \\
\hline - Soaps for hand washing & 68 & 86.1 & 11 & 13.9 \\
\hline - Clean latex gloves & 70 & 88.6 & 9 & 11.4 \\
\hline - Sterile latex gloves & 23 & 29.1 & 56 & 70.9 \\
\hline - Heavy duty gloves & 67 & 84.8 & 12 & 15.2 \\
\hline - Standard masks (normal breathing protectors) & 69 & 87.3 & 10 & 12.7 \\
\hline - Single-use plastic gowns & 40 & 50.6 & 39 & 49.4 \\
\hline - Disinfectants for surfaces & 70 & 88.6 & 9 & 11.4 \\
\hline - Enough syringes (proportionate to the use) & 26 & 32.9 & 53 & 67.1 \\
\hline $\begin{array}{l}\text { - Cannula and IV devices were enough (proportionate to } \\
\text { the use) and confirmed to standards (with injection site } \\
\text { and other special for glass bottles) }\end{array}$ & 14 & 17.7 & 65 & 82.3 \\
\hline - Soaps for instrumental cleaning & 68 & 86.1 & 11 & 13.9 \\
\hline - Specific indicators for sterilization & 0 & 0.0 & 79 & 100.0 \\
\hline - Tools for environmental cleaning (jug and pile) & 72 & 91.1 & 7 & 8.9 \\
\hline $\begin{array}{l}\text { - Waste segregation tools (colored bags, black bags, safety } \\
\text { boxes) }\end{array}$ & 71 & 89.9 & 8 & 10.1 \\
\hline \multicolumn{5}{|l|}{ II- At pharmacy: } \\
\hline - Alcohol & 5 & 6.3 & 74 & 93.7 \\
\hline - Skin disinfectants & 46 & 58.2 & 33 & 41.8 \\
\hline - Disinfectants for hand washing (betadine foam) & 0 & 0.0 & 79 & 100.0 \\
\hline - Heat intolerable disinfectants for instruments & 0 & 0.0 & 79 & 100.0 \\
\hline - Single-use treatments (proportionate to the use) & 79 & $\begin{array}{c}100 . \\
0\end{array}$ & 0 & 0.0 \\
\hline $\begin{array}{l}\text { - Sterile water ampoules to dilute medicines (proportionate } \\
\text { to the use) }\end{array}$ & 75 & 94.9 & 4 & 5.1 \\
\hline - Refills solutions confirmed to the standards (self-sealed) & 71 & 89.9 & 8 & 10.1 \\
\hline
\end{tabular}


Table (6): Mean percentage of infection control measures in the study sites, Assiut Governorate, 2014

\begin{tabular}{|l|c|c|c|c|c|c|}
\hline \multirow{2}{*}{$\begin{array}{c}\text { Infection control } \\
\text { measures }\end{array}$} & $\begin{array}{c}\text { Al-Fat-h } \\
\text { District }\end{array}$ & $\begin{array}{c}\text { Rural } \\
\text { Assiut }\end{array}$ & $\begin{array}{c}\text { West Assiut } \\
\text { Neighborhood }\end{array}$ & $\begin{array}{c}\text { East Assiut } \\
\text { Neighborhood }\end{array}$ & $\begin{array}{c}\text { Sedfa } \\
\text { District }\end{array}$ & $\begin{array}{c}\text { P- } \\
\text { val } \\
\text { ue }\end{array}$ \\
\hline $\begin{array}{l}\text { I-Administrative } \\
\text { measures : }\end{array}$ & & & & & & \\
\hline Mean \pm SD & $58.99 \pm 5.11$ & $62.93 \pm 3.77$ & $64.98 \pm 6.09$ & $62.74 \pm 4.75$ & $58.83 \pm 7.98$ & $0.011^{*}$ \\
\hline Range & $44.1-64.7$ & $55.9-73.5$ & $58.8-76.5$ & $52.9-70.6$ & $50.0-76.5$ & \\
\hline $\begin{array}{l}\text { II-Unit } \\
\text { cleanliness: }\end{array}$ & & & & & & \\
\hline Mean \pm SD & $17.73 \pm 6.04$ & $23.59 \pm 12.84$ & $34.99 \pm 14.95$ & $36.05 \pm 16.27$ & $17.15 \pm 4.16$ & $0.000 *$ \\
\hline Range & $13.0-30.4$ & $13.0-69.6$ & $19.6-76.1$ & $19.6-71.7$ & $13.0-23.9$ & \\
\hline \hline I-Infrastructure: & & & & & & \\
\hline Mean \pm SD & $27.79 \pm 13.24$ & $53.27 \pm 17.31$ & $32.59 \pm 15.12$ & $25.23 \pm 3.45$ & $35.55 \pm 4.320 .000 *$ \\
\hline Range & $5.6-63.9$ & $25.0-72.2$ & $25.0-77.8$ & $22.2-33.3$ & $27.8-41.7$ & \\
\hline \hline -Requirements: & & & & & & \\
\hline Mean \pm SD & $42.92 \pm 7.92$ & $55.89 \pm 23.21$ & $32.27 \pm 16.41$ & $54.38 \pm 19.04$ & $48.00 \pm 7.25$ & $0.003 *$ \\
\hline Range & $27.5-57.5$ & $5.0-80.0$ & $10.0-62.5$ & $2.5-85.0$ & $37.5-60.0$ & \\
\hline V-Procedures: & & & & & & \\
\hline Mean \pm SD & $46.62 \pm 8.78$ & $56.12 \pm 3.89$ & $46.26 \pm 6.43$ & $46.26 \pm 6.78$ & $51.84 \pm 3.10$ & $0.000 *$ \\
\hline Range & $18.4-59.0$ & $48.0-63.6$ & $34.3-55.0$ & $35.2-55.1$ & $46.2-54.8$ & \\
\hline Total score: & & & & & & \\
\hline Mean \pm SD & $43.48 \pm 7.05$ & $53.52 \pm 5.33$ & $43.56 \pm 6.22$ & $45.66 \pm 5.08$ & $47.94 \pm 2.83$ & $0.000 *$ \\
\hline Range & $22.9-55.9$ & $42.0-63.1$ & $32.6-53.5$ & $37.7-53.6$ & $43.4-51.1$ & \\
\hline
\end{tabular}


Dr. Ekram Mohamed Abdel Khalek

Title: Assistant Professor of Public Health and Community Medicine

Mail address: Public Health and Community department, Assiut Faculty of

\section{Medicine}

E-mail address: habeba2002eg@yahoo.com

\section{Prof. Dr. Mohammad Hassan Qayed}

Title: Professor of Public Health and Community Medicine

Mail address: Public Health and Community Department, Assiut Faculty of Medicine E-mail address: mohammad.qayed@yahoo.com

\section{Prof. Dr. Enas Mohamed Abd El-Megeed}

Title: Professor of Microbiology and Immunology

Mail address: Microbiology and Immunology Department, Assiut Faculty of Medicine

\section{Noha Abdallah Abdelnaby Omar}

Title: Primary Health Care Practitioner

Mail address: Assiut Health Directorate

E-mail address: nohaabdalla@yahoo.com 